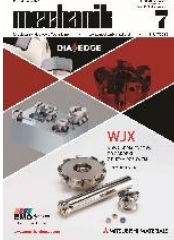

How to cite this article:

Authors: Ewa Golińska, Dariusz Plinta

Title of article: „Management system requirements for quality costs in the automotive industry”

Mechanik, No. 7 (2019)

DOI: https://doi.org/10.17814/mechanik.2019.7.52

\title{
Management system requirements for quality costs in the automotive industry
}

\author{
EWA GOLIŃSKA \\ DARIUSZ PLINTA*
}

Mgr inż. Ewa Golińska, egolinska@ath.bielsko.pl, https://orcid.org/0000-0003-1817-9582 - Akademia Techniczno-Humanistyczna w

Bielsku-Białej, Bielsko-Biała, Polska

Dr hab. inż. Dariusz Plinta, prof. ATH, doplinta@ath.bielsko.pl, https://orcid.org/0000-0002-4638-5319 - Akademia Techniczno-Humanistyczna w Bielsku-Białej, Bielsko-Biała, Polska

In the article, the requirements of IATF 16949 in terms of quality costs in the automotive industry have been presented. The obligatory requirements are the need to identify, calculate and report only costs of poor quality - internal and external. In addition, the requirement is to demonstrate the relationship between the objectives of individual processes or activities identified in the organization with the vision, mission and strategy of the company. To illustrate this relationship, the organization used a balanced scorecard (BSC). The methodology of conduct in this area has also been presented in the article. KEYWORDS: production engineering, technical specification IATF 16949, automotive industry, lowquality costs, reporting for the management system review

\section{Introduction}

Quality costs are generated in every enterprise, and the very awareness of these costs is the first step to manage them. The next step is the ability to measure them [1]. The financial statement of data on the quality cost account in the enterprise, as well as forecasting based on historical data, is a system requirement of the current standard for the automotive industry - IATF 16949 specification.

This requirement - after the 2016 amendment - has been extended to include the need to link the degree of implementation of measurable qualitative objectives, relating to the measurement of the so-called poor quality, with a strategic aspect of the company's operations. The paper presents basic issues regarding the conditions of meeting this requirement.

\section{Quality costs and their calculation}

By analyzing the literature on the issue of costs, it is difficult to find one common definition. Often one can also come across different interpretations of the name. Economists define quality costs as the sum of costs incurred to produce a given product assuming its quality level. In turn, quality engineers, like authors of this publication, treat quality costs as a separate part of their own manufacturing costs - their reduction can significantly reduce the total production costs.

Global quality management guru - Joseph Juran, who created the concept of the cost of quality as an economic measure of quality in organizations - defined the cost of quality as an expense that is incurred to provide products with usability [2]. The European Foundation for Quality Management says that the cost of quality is spending on verifying features, detecting and removing defects. Also, norm providers in already outdated standards (PN-ISO 8402: 1996, PN-ISO 9004-3: 1994) paid special attention to the identification and valuation of actions aimed at achieving an acceptable level of quality and actions resulting from inadequate quality supervision. However, recent amendments to standards, both with reference to ISO 9000: 2015 and ISO 9001: 2015, do not address the issue of quality costs. Information on the measurement of efficiency, which also relates to the quality aspect, can only be found in the recommendations of ISO 9004: 2018 and in the technical specification IATF 16949 , requirements of which in the field of low quality costs are addressed in the paper [1].

In the early 1950s, Joshep M. Juran and Armand V. Feigenbaum took up scientific analysis of quality costs for the first time. At that time, the quality costs were only related to the final inspection. Due to market changes, other costs related to quality appeared. There was also a need to create a general concept of recording the 
quality costs, as well as their assessment and possibilities of minimization. In the 1960s, Feigenbaum published the first formal concept for classifying the quality costs [3]. Over the years, many structural quality cost models have emerged. A common feature and basis for all currently developed approaches is the division of quality costs into three basic groups: error costs, evaluation costs and prevention costs. Contemporary structural models of quality costs are still based on the three categories mentioned above, while also taking into account the significance of product user safety and a rational approach to land resources. Modern risk concepts of structural models also take into account the risk factor - both on the part of the client and the organization itself as well as other elements of the environment $[4,5]$.

\section{Requirements in the area of cost reporting regarding quality in the automotive industry}

Management systems in the automotive industry are built on the basis of the requirements of technical specification IATF 16949. This standard covers the entire product creation cycle - from the organization of the enterprise and its quality system, through market analysis, product and process design stage, production, control activities and testing, risk assessment, taking corrective, preventive and improving actions, until the shipment of the finished product to the customer. The main goal of this system is to create effective interactions between the organization's quality policy and its measurable qualitative goals and the simultaneous planning of how to achieve these goals.

The new edition of the IATF 16949: 2016 standard has significantly changed the approach to reporting results of organizational activities. Chapter 9 of the current standard requires top management to review the quality management system at planned intervals (this requirement has not changed) to ensure that the system is appropriate and effective. Suitability is simply defined as the ability of processes to provide products and services that comply with legal requirements, the customer, implemented norms and standards, as well as the organization's own requirements. Suitability indicates the ability of processes to maintain current process results. Inadequacy of the process is generally associated with insufficient resources. Effectiveness, sometimes called adaptability, is understood as the ability of processes to meet the changing expectations of interested parties. Therefore, the management review must assess three aspects:

- to what extent the organization meets the requirements (suitability),

- to what extent the organization maintains results (appropriateness),

- how effectively the organization reacts to variability (effectiveness).

Another requirement for conducting management reviews, which appeared as a novelty in the current specification, is to link the quality management system assessment with the strategic direction of organization development [6].

A management review makes sense when the input data for this process is prepared in an appropriate, reliable manner. The completeness of these data, as well as building them on one of the principles of quality management - based on facts - is the key to obtaining the added value from the effort put into conducting the review. The ninth point of the reference standard indicates with details the requirements for the preparation of input data for management review. However, the purpose of the paper is not to discuss all requirements in this area, but to focus on one of them - the report on the assessment of non-compliance costs (IAFT 16949: 2016, point 9.3.2.1.a).

The costs of non-compliance, i.e. the costs of poor quality, in the area of requirements of the current technical specification include the costs of poor internal and external quality. The report on the cost of non-compliance should include both an assessment of the achievement of the objectives (relevance) and a trend analysis (appropriateness).

\section{Recording and calculation of non-compliance costs in the analyzed enterprise}

The analysis presented in the paper was carried out in a large automotive company that manufactures passenger cars in a multi-version and multi-range mass production system. The analyzed production line is an example of mass production, focused on the individual needs of the customer, and while at the initial stage the production is repetitive, at the final stage (analyzed at work), it is an example of individual production. In other words, each car leaving the flexible assembly line is configured on request and the number of final versions is close to 35,000. An integrated management system (ISO 9001: 2015 + ISO 14001: 2015 + ISO 45001: 2018) has been implemented in the factory and sector requirements for the automotive industry (IATF 16949: 2016).

The analysis was made looking at the costs of quality from a financial perspective and internal processes. Before taking any action in the organization, a procedure was created to harmonize the approach to measuring the effectiveness of quality-related activities.

Another problem was the selection of the cost accounting method. In the case of production with a multivariant course and a highly diversified assortment, averaging the share of quality costs in own costs resulted in 
distorted results, which in turn also led to decisions based on incorrect data. Unit production, small-lot production (in the analyzed organization, this type of production occurs at the final sections of the assembly) is characterized by relatively large share of indirect costs in the total pool of production costs, therefore in the case of quality cost accounting, the authors decided to use the activity costing.

The company had already had activity-based cost accounting, thus there was no need to introduce a new or additional quality cost accounting system. An additional quality costs account and additional analytical accounts were created in the company's settlement sheet to record detailed quality costs indicated by the project group. The working group proposed a classification of costs, dividing them into internal and external non-compliance costs (defects).

In addition, the company decided to analyze the costs of prevention, research and evaluation as well as the costs of external quality assurance. In addition, appropriate forms have been prepared to facilitate the creation of records, especially in areas of direct production, in relation to recording the internal defects (fig. 1).

There was an increase in the repeatability of activities in the areas responsible for identifying, assigning and analyzing the quality data, which made these activities more rational.

\begin{tabular}{|l|l|l|}
\hline COST GROUP & ACTION & COST Q3 2018 \\
\hline internal defect costs & & \\
\hline costs of external defects & & \\
\hline research and evaluation costs & & \\
\hline prevention costs & & \\
\hline costs for external quality assurance & & \\
\hline & & \\
\hline research and evaluation costs & COST \\
\hline ACTION & \\
\hline supply quality management & \\
\hline suppliers evaluation & \\
\hline $\begin{array}{l}\text { maintenance and calibration/checking of control and } \\
\text { measuring instruments }\end{array}$ & \\
\hline destruction tests (in relation to the cost of material) & \\
\hline internal auditing costs & \\
\hline SPC costs & total costs \\
\hline
\end{tabular}

Fig. 1. Forms for collecting documented information regarding quality costs (fragment - regarding research and evaluation costs)

\section{Non-compliance cost reporting}

Previously, the authors described the requirements in the area of reporting in relation to the cost of non-compliance. The report in its traditional form, presenting only financial indicators, does not meet these requirements. Therefore, a decision was made to report the cost of non-compliance in the form of a balanced scorecard (BSC).

The card is not without reason called balanced - it is characterized by a balance between measures related to historical data (relevance) and measures predicting future events (appropriateness). Cascading a balanced scorecard into processes and activities identified in the company was applied. Each card (at each level) has four perspectives - financial perspective, customer perspective, internal processes perspective, growth and learning perspective. Fig. 2 presents a fragment of a balanced scorecard, which was a supplement to financial reporting, reported as input to the management review. 


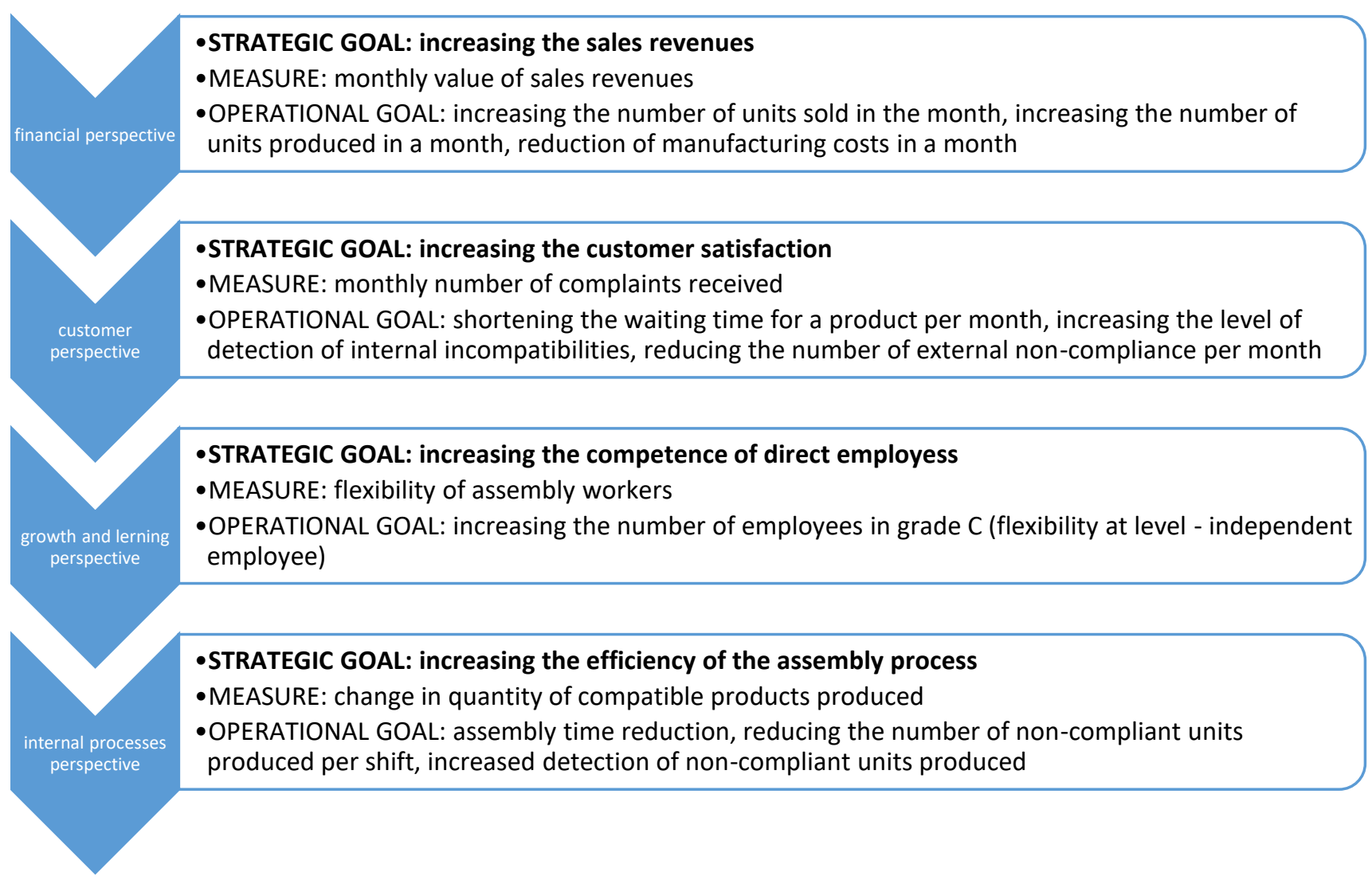

Fig. 2. BSC for the assembly process - fragment

An example of the process was the assembly process. Formulation of goals for processes and activities took place through the concretization of strategic goals with BSC. For each of the perspectives for the selected sample process, the following items were determined: strategic goals, operational goals and measures. The scorecard was supplemented with indicators for measuring the degree of the goal achievement, which allowed for translating the organizational strategy contained in the company's quality policy to specific, measurable goals to be implemented at various levels and in different areas of the organization.

\section{Summary}

The IATF automotive standard for the automotive industry is one of the few normalized standards, the requirements of which include quality cost analysis. Although the obligatory approach to the calculation of quality costs covers only the costs of non-compliance, many companies opt for a broader calculation, taking into account also the costs of prevention, research and evaluation as well as external quality assurance. One of the requirements of the new edition of the IATF standard is linking the strategic goals of the organization with the financial indicators related to the calculation of quality costs and setting trends in this area. A tool enabling top management to make a comprehensive assessment of the effectiveness and efficiency of conducted activities is the concept of using a balanced scorecard (BSC) presented in the paper, which universally allows for the implementation of organizational strategy on the ground of individual processes and activities carried out by specific units or employee groups - a measure of achievement their success is determined on the basis of measurable indicators. The use of the balanced scorecard in an enterprise provides automotive industry organizations to maintain the certificate (by directly meeting the requirements of the standard), and also significantly supports the decision-making process at managerial levels.

\section{REFERENCES}

[1] Golińska E., Zemczak M. „Analiza niezgodności w procesie montażu” Wokół inżynierii produkcji. 2016. Monografia. Wydawnictwo AGH, 2016.

[2] Juran J.M., Gryna F.M. „Jakość - projektowanie - analiza”. Warszawa: Wydawnictwo Naukowo-Techniczne, 1974.

[3] Feigenbaum A.V. „Total Quality Control. Engineering and Management”. New York: McGraw Hill Book Company, 1961. 
[4] Zymonik Z. „Koszty jakości w zarządzaniu przedsiębiorstwem”. Oficyna Wydawnicza Politechniki Wrocławskiej, 2003.

[5] Zymonik Z., Hamrol A., Grudowski P. „Zarządzanie jakościq i bezpieczeństwem”. Warszawa: PWE, 2013. [6] Specyfikacja techniczna dla branży motoryzacyjnej - IAFT 16949:2016. 